\title{
PENGARUH SENI PERTUNJUKAN TERHADAP TINGKAT KUNJUNGAN DI DAYA TARIK WISATA BUDAYA TAMAN NUSA GIANYAR, BALI
}

\author{
Made Darmiati \\ Program Studi Manajemen Bisnis Perjalanan, Politeknik Pariwisata Bali \\ Jl. Dharmawangsa Kampial, Nusa Dua Bali \\ darmiati@ppb.ac.id
}

Received: Agustus, 2020 $\quad$ Accepted: September, 2020

Published: September, 2020

\begin{abstract}
This study aims to determine the influence of performing arts to the level of tourist visits in the Park Nusa Gianyar Bali. The results showed (1) that there was a real positive effect between Barong dance performances (X1) individually to visit in Taman Nusa (Y). (2) that there is a real positive influence between the performing arts of Angklung instrument (X2) individually to visit in Taman Nusa (Y). (3) that there is a real positive influence between dance performances of the archipelago (X3) individually to visit in Taman Nusa (Y). Can be concluded that the performing arts as a tourism product of PT. Taman Nusa, has a strong or very significant influence on the level of tourist visits to Taman Nusa. So that PT. Taman Nusa to be able to develop new innovations relating to the performing arts as a great potential in tourism products owned.
\end{abstract}

Keywords: performing arts, tourist visit, culture tourism

\begin{abstract}
Abstrak
Penelitian ini bertujuan untuk mengetahui pengaruh seni pertunjukan terhadap tingkat kunjungan wisatawan di Taman Nusa Gianyar Bali. Hasil penelitian menunjukan (1) bahwa ada pengaruh positif yang nyata antara seni pertunjukan tari Barong (X1) secara individu terhadap kunjungan di Taman Nusa (Y). (2) bahwa ada pengaruh positifyang nyata antara seni pertunjukan instrumen angklung (X2) secara individu terhadap kunjungan di Taman Nusa (Y). (3) bahwa ada pengaruh positif yang nyata antara seni pertunjukan tari nusantara (X3) secara individu terhadap kunjungan di Taman Nusa (Y). Dapat disimpulkan bahwa seni pertunjukan sebagai produk wisata dari PT. Taman Nusa, memiliki pengaruh kuat atau sangat signifikan terhadap tingkat kunjungan wisatawan ke Taman Nusa. sehingga PT. Taman Nusa untuk dapat mengembangkan inovasi - inovasi baru yang berkaitan dengan seni pertunjukan sebagai potensi besar dalam produk wisata yang dimiliki.
\end{abstract}

Kata Kunci: seni pertunjukan, kunjungan wisatawan, pariwisata budaya

\section{PENDAHULUAN}

Pertunjukan Hasil budaya atau hasil karya seni adalah salah satu atraksi yang diminati oleh wisatawan MICE. Hadirnya kegiatan MICE baik yang bersifat 
nasional maupun internasional menjadi bukti kepercayaan masyarakat dunia untuk melakukan aktivitas MICE di Indonesia. Faktor pendukung seperti pertumbuhan ekonomi yang stabil, stabilitas politik dan kemanan yang semakin baik, dukungan pemerintah serta infrastruktur yang memadai semakin menunjukkan potensi Indonesia untuk menarik konsumen MICE (Koran Kompas 2015)

Seni pertunjukan merupakan salah satu sub sektor ekonomi kreatif yang memiliki peluang besar dalam meningkatkan pendapatan dosmetik bruto (Ahman Sya, 2014:43). Seni pertunjukan di setiap daerah di Indonesia memiliki keunikan dan kekhasan serta memiliki nilai, norma, dan fungsi bagi masyarakat pendukungnya. Karena keunikan dan kekhasan yang dimiliki oleh seni pertunjukan dari masing-masing daerah di Indonesia. Hal ini menjadi atraksi wisata yang menarik bagi wisatawan domestik maupun wisatawan mancanegara.

Taman Nusa adalah salah satu venue yang didirikan oleh PT.Taman Nusa yang berlokasi di Taman Bali - Banjarankan Banjar Blahpane Kelod, Desa Sidan, Gianyar Bali. Taman Nusa adalah salah satu venue yang menyediakan tempat pertunjukan serta menyelenggarakan event seperti incentive. Taman Nusa merupakan destinasi wisata yang menyediakan jasa pertunjukan seni tradisional yang berasal dari berbagai daerah dan provinsi yang ada di
Indonesia seperti seni pertunjukan barong, seni pertunjukan angklung, seni pertunjukan tari nusantara dan yang lainnya, Terdapat pula Kampung Budaya dimana ada lebih dari 60 rumah adat tradisional, hal ini disampaikan oleh James Soma selaku manajer art and culture yang ada di Taman Nusa Gianyar Bali.

Event-event yang diselenggarakan di Taman Nusa semuanya berupa incentiveyang diantaranya adalah APEC CEO Summit yang diselenggarakan pada bulan October 2013, kemudian World Culture Forum yang juga diadakan pada tahun2013, setelah itu ada beberapa event yang dilakukan di Taman Nusa pada tahun 2014 yaitu, Ikatan Dokter Internis Bali, Team Building Accor Group, Staff Outing Rama Beach Hotel, dan Sosialisasi TKI Disnaker. Pada tahun April 2015 ada satu event yang diselenggarakan di Taman Nusa yaitu Forum Raja dan Sultan SeNusntara. Pada kegiatan-kegiatan tersebut Taman Nusa sebagai penyedia venue dapat menyajikan pertunjukan seni dan memberikan pelayanan yang baik sebagai sebuah produk wisata yang akan ditawarkan kepada clientdan pengunjung.

Kunjungan wisatawan ke Taman Nusa untuk melihat dan menyaksikan Bangunan adat tradisional dan atraksinya (pertunjukan seni) yang ada di Taman Nusa mengalami perubahan jumlah kunjungan wisatawan yang dapat dilihat pada tabel 1.4 berikut:

Tabel 1: Jumlah Kunjungan wisatawan ke Taman Nusa Bali pada tahun 2019 [Sumber: Sumber: Taman Nusa, 2019]

\begin{tabular}{ccc}
\hline Tahun & Jumlah Kunjungan & Pertumbuhan ( \% ) \\
\hline 2017 & 26,610 & \\
2018 & 103,348 & 3,04 \\
2019 & 99,906 & 0,03 \\
\hline
\end{tabular}

Berdasarkan data pada Tabel 1.3 dapat dilihat, bahwaterjadi perubahan jumlah kunjungan, terlihat pada tahun 2017 jumlah kunjungan ke Taman Nusa 
sebesar 26,610 kunjungan lalu pada tahun 2018 ada 103,348 kunjungan dengan pertumbuhan 3,04\%, dan pada tahun 2019 ada 99,906 kunjungan dengan pertumbuhan 0,03\%, kunjungan tertinggi ada di tahun 2014 namun pada tahun berikutnya kunjungan ke taman nusa tidak stabil bahkan menurun. Mengacu kepada latar belakang, maka tujuan penelitian ini adalah untuk mengetahui Pengaruh Seni Pertunjukan Terhadap Tingkat Kunjungan wisatawan di Taman Nusa Gianyar Bali.

\section{METODE PENELITIAN}

Dalam penelitian ini adapun teknik pengambilan sampel yang digunakan adalah teknik Accidental Sampling yaitu teknik penentuan sampel berdasarkan kebetulan (Sugiyono, 2013: 85 ). Responden yang secara kebetulan melakukan kunjungan ke Taman Nusa Gianyar Bali. Untuk menentukan besarnya sampel digunakan ketentuan jumlah pernyataan dikalikan 5 (Ferdinand, 2013). Sehingga jumlah sampel yang dibutuhkan dalam penelitian ini adalah $20 \times 4=80$ responden.

Data yang digunakan biasanya berskala interval atau rasio (Supardi 2013:229). Analisis regresi berganda digunakan untuk mengetahui seberapa besar pengaruh variabel bebas yaitu: Pertunjukan Seni Tari Tradisional (X1), Pertunjukan musik Tradisional(X2), terhadap tingkat kunjungan di Taman Nusa (Y). Adapun bentuk persamaan regresi linier berganda yang digunakan dalam penelitian ini sebagai berikut :

$$
\mathrm{Y}=\mathrm{a}+\mathrm{b} 1 \mathrm{X} 1+\mathrm{b} 2 \mathrm{X} 2+\varepsilon
$$

Setelah dilakukan transformasi logaritma, maka persamaan regresi linier berganda adalah sebagai berikut $10 \log \mathrm{Y}=\mathrm{a}+\mathrm{b} 110 \log \mathrm{X} 1+\mathrm{b} 210 \log \mathrm{X} 2+\varepsilon$ Keterangan :

$\begin{array}{lll}\mathrm{Y} & =\text { Tingkat Kunjungan } \\ \mathrm{a} & =\text { Konstanta } \\ \mathrm{b} 1, \text { dan b2, } & =\text { Koefisien regresi } \\ \text { 10log X1 } & \text { Pertunjukan } & \text { Tari } \\ \text { Tradisional } & & \end{array}$

$10 \log \mathrm{X} 2=$ Pertunjukan Musik Tradisional

Pengujian $\mathrm{t}$ (t-test) pada dasarnya menunjukkan seberapa jauh pengaruh variabel independen secara individual dalam menerangkan variasi variabel dependen. Langkah-langkah pengujiannya adalah sebagai berikut:

1) Perumusan Hipotesis Ho: b1 $=0$, yang berarti variabel independen bukan merupakan variabel penjelas yang signifikan terhadap variabel dependen. Ha: b1 > 0, yang berarti berarti variabel tersebut merupakan penjelas yang signifikan terhadap variabel dependen.

2) Penentuan Statistik Tabel dalam penelitian ini digunakan $\alpha$ (taraf kepercayaan $)=5 \%$ dan $\mathrm{df}$ (degrrees of freedom $=$ derajat bebas) $=\mathrm{n}-\mathrm{k}-1$ $=36-2-1=33$.

3) Kriteria Penerimaan atau Penolakan Hipotesis adapun kriteria penerimaan atau penolakan hipotesis yang diajukan di atas adalah sebagai berikut:

Ho diterima apabila $t_{\text {hitung }} \leq t_{\text {tabel }}$

Ho ditolak apabila $t_{\text {hitung }}>t_{\text {tabel }}$

4) Penentuan $t_{\text {hitung }}$ Penentuan thitung akan dilakukan melalui program SPSS for Windows versi 22.0

5) Penarikan Kesimpulan apabila $t_{\text {hitung }}>$ $t_{\text {tabel, }}$ maka Ho ditolak, artinya ada pengaruh yang signifikan. Apabila $t_{\text {hitung }}<t_{\text {tabel}}$, maka Ho diterima, artinya tidak ada pengaruh.

Pengujian Varians (f test) Uji F digunakan pada dasarnya menunjukkan apakah semua variabel independen yang dimasukkan ke dalam model mempunyai pengaruh secara bersama-sama terhadap variabel dependen atau terikat (Ghozali, 2006:10). Langkah- langkah pengujiannya sebagai berikut:

Perumusan Hipotesis Ho : b1 = b2 = 0 , berarti tidak terdapat pengaruh positif secara simultan variabel independen terhadap variabel dependen, $\mathrm{Ha}: \mathrm{b} 10$ dan atau b2回 0 , berarti terdapat pengaruh positif secara simultan variabel independen terhadap variabel. 


\section{HASIL DAN PEMBAHASAN}

\subsection{Analisis Regresi Linier Berganda}

Model yang digunakan dalam menganalisis variabel-variabel yang mempengaruhi kunjungan di Taman Nusa adalah model analisis regresi linear berganda dengan bantuan program SPSS versi 15. Dalam model analisis regresi linear berganda yang menjadi variabel terikatnya adalah kunjungan di Taman Nusa sedangkan yang menjadi variabel bebasnya adalah seni pertunjukan tari Barong, seni pertunjukan instrumen angklung dan seni pertunjukan tari nusantara. Hasil regresi linier berganda ditujukkan pada Tabel 2.

Tabel 2: Hasil Analisis Regresi Linier Berganda. Judul Gambar [Sumber: Taman Nusa 2019]

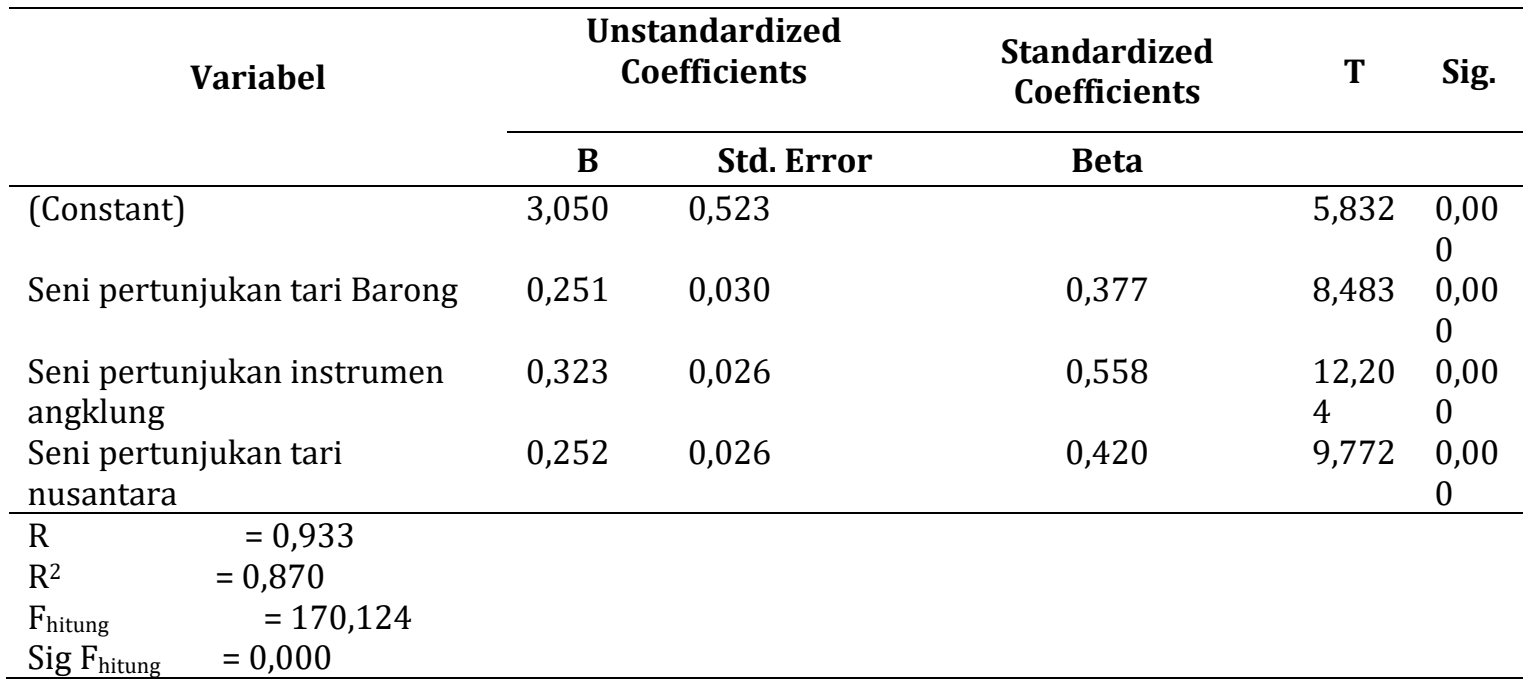

Dari hasil analisis regresi pada Tabel 4.1 di atas dapat disusun persamaan regresi sebagai berikut:

$$
\mathrm{Y}=3,050+0,251 \mathrm{X} 1+0,323 \mathrm{X} 2+
$$
$0,252 X 3$

Berdasarkan nilai a, b1, b2, dan b3, diperoleh persamaan garis regresi linear berganda antara seni pertunjukan tari Barong, seni pertunjukan instrumen angklung dan seni pertunjukan tari nusantara terhadap kunjungan di Taman Nusa memberikan informasi bahwa:

1) $a=3,050$ artinya apabila tidak ada perhatian terhadap seni pertunjukan tari Barong, seni pertunjukan instrumen angklung, dan seni pertunjukan tari nusantara maka skor kunjungan di Taman Nusa adalah rata-rata sebesar 3,050

2) $\mathrm{b} 1=0,251$ artinya apabila seni pertunjukan instrumen angklung (X2) dan seni pertunjukan tari nusantara (X3) dianggap konstan maka meningkatnya skor seni pertunjukan tari Barong (X1) sebesar satu satuan akan diikuti oleh meningkatnya skor kunjungan di Taman Nusa (Y) sebesar 0,251.

3) $\mathrm{b} 2=0,323$ artinya apabila seni pertunjukkan tari barong (X1) dan seni pertunjukan tari nusantara (X3) dianggap konstan maka meningkatnya seni pertunjukan instrumen angklung (X2) sebesar satu satuan akan diikuti oleh meningkatnya skor kunjungan di Taman Nusa (Y) sebesar 0,323.

4) b3 = 0,252 artinya apabila seni pertunjukan tari Barong (X1) dan seni pertunjukan instrumen angklung (X2) dianggap konstan maka meningkatnya seni pertunjukan tari nusantara (X3) sebesar satu satuan akan diikuti oleh meningkatnya skor kunjungan di Taman Nusa (Y) sebesar 0,252. 
Dengan demikian, dapat dinyatakan bahwa tinggi rendahnya kunjungan di Taman Nusa dipengaruhi secara serempak oleh seni pertunjukan tari Barong, seni pertunjukan instrumen angklung dan seni pertunjukan tari nusantara.

\subsection{Analisis Determinasi}

Analisis ini digunakan untuk mengetahui persentase besarnya pengaruh variabel yang diteliti, yaitu antara variabel bebas seni pertunjukan tari Barong (X1), seni pertunjukan instrumen angklung (X2) dan seni pertunjukan tari nusantara (X3) secara simultan terhadap variabel terikat kunjungan di Taman Nusa (Y).

Rumus untuk menentukan besarnya koefisien determinasi (D) adalah D = R2 X $100 \%$. Besarnya R2 = 0,870, maka:

$$
\begin{aligned}
\mathrm{D} & = & \mathrm{R} 2 \mathrm{X} 100 \% \\
& = & (0,870) \times 100 \% \\
& = & 87 \%
\end{aligned}
$$

Koefisien determinasi sebesar $87 \%$, berarti pengaruh seni pertunjukan tari Barong (X1), seni pertunjukan instrumen angklung (X2) dan seni pertunjukan tari nusantara (X3) secara simultan terhadap kunjungan di Taman Nusa (Y) adalah sebesar 87\%. Sisanya sebesar $100 \%-87 \%=13 \%$ dipengaruhi oleh faktor lain yang tidak diteliti pada kesempatan ini. Pengaruh seni pertunjukan tari Barong (X1), seni pertunjukan instrumen angklung (X2) dan seni pertunjukan tari nusantara (X3) sebesar $87 \%$ ini, menunjukkan besarnya persentase pengaruh seni pertunjukan tari Barong (X1), seni pertunjukan instrumen angklung (X2) dan seni pertunjukan tari nusantara (X3), untuk meningkatkan kunjungan di Taman Nusa (Y) pada.

\subsection{F- test}

Untuk menguji nyata-tidaknya pengaruh variabel bebas seni pertunjukan tari Barong (X1), seni pertunjukan instrumen angklung (X2) dan seni pertunjukan tari nusantara (X3) secara simultan terhadap variabel terikat kunjungan di Taman Nusa (Y), maka dilakukan uji signifikasi dengan uji-F (Ftest) yang langkah-langkah pengujiannya adalah sebagai berikut:

1) Perumusan Hipotesis HO : b1,2,3 = 0 berarti bahwa tidak ada pengaruh yang nyata antara seni pertunjukan tari Barong (X1), seni pertunjukan instrumen angklung (X2) dan seni pertunjukan tari nusantara (X3) secara simultan dengan kunjungan di Taman Nusa (Y). Hi : b1,2,3 >0 berarti ada pengaruh positif yang nyata antara seni pertunjukan tari Barong (X1), seni pertunjukan instrumen angklung (X2) dan seni pertunjukan tari nusantara (X3) secara simultan dengan kunjungan di Taman Nusa (Y)

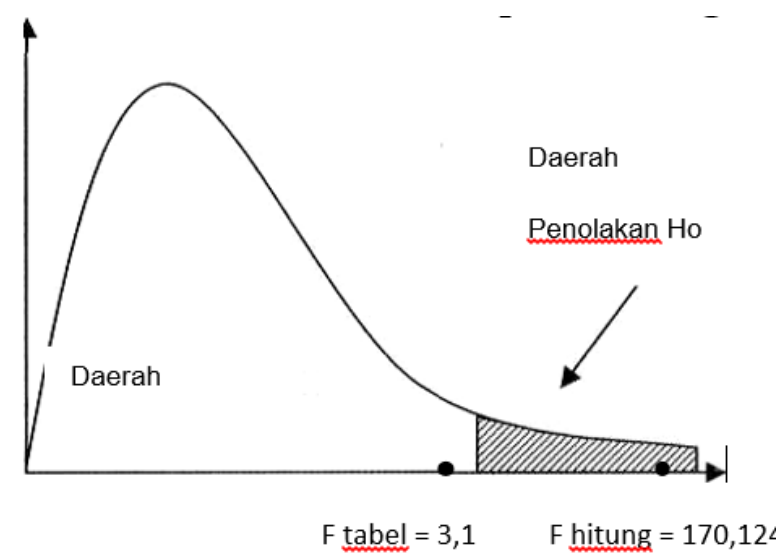

Gambar 1: Kriteria Penerimaan/Penolakan Hipotesis Dengan Uji-F 
2) Penentuan Statistik Tabel Dalam pengujian ini digunakan Ftabel = $\mathrm{F}$ (??;fn/dfd). Besarnya taraf kepercayaan (Level of significancy) yang dipakai dalam pengujian ini adalah $\alpha=5 \%$ dengan dfn (degrees of freedom numerator $=$ derajat bebas pembilang) $=\mathrm{k}-1=3-1=2$, dan dfd (degres of freedom denominator $=$ derajat bebas penyebut) $=\mathrm{n}-\mathrm{k}-1=80-3-1=76$. Sesuai dengan Tabel $F$ menurut Husaini Usman (1995:313) pada Lampiran 7 besarnya $\mathrm{F}$ (19;dfn/dfd) untuk $\mathrm{F}(5 \% ; 76)$ adalah $=3,1$.

3) Penentuan Fhitung

Diketahui:

$\mathrm{F}=170,124$

d. Gambar Daerah Penerimaan dan

Penolakan Ho

Kriteria Pengujian

Jika $\mathrm{F}$ hitung $>\mathrm{F}$ tabel $(3,10)$ maka Ho ditolak.

Jika $\mathrm{F}$ hitung $\leq \mathrm{F}$ tabel $(3,10)$ maka Ho diterima.

4) Keputusan

Sesuai hasil perhitungan dan gambar

1 diperoleh $\mathrm{F}$ hitung $=170,124$ dibandingkan dengan nilai Ftabel $=3,10$, maka ternyata nilai Fhitung lebih besar dari nilai Ftabel, dan Fhitung berada pada daerah penolakan HO. Oleh karena itu, HO ditolak dan Hi diterima. Ini berarti bahwa pada taraf $\alpha=5 \%$ secara simultan seni pertunjukan tari Barong (X1), seni pertunjukan instrumen angklung (X2) dan seni pertunjukan tari nusantara (X3), memiliki pengaruh positif yang signifikan (nyata) terhadap kunjungan di Taman Nusa (Y).

\section{5 t-test}

Uji ini digunakan untuk menguji signifikasi masing-masing koefisien regresi, sehingga diketahui apakah secara parsial seni pertunjukan tari Barong berpengaruh terhadap kunjungan di Taman Nusa adalah memang nyata terjadi (signifikan) atau hanya diperoleh secara kebetulan.

Langkah-langkah uji statistiknya adalah:

1) Pengaruh seni pertunjukan tari Barong (X1) secara individu terhadap kunjungan di Taman Nusa (Y) dengan membuat Formulasi Hipotesis

H0 : b1 =0, berarti tidak ada pengaruh yang nyata antara seni pertunjukan tari Barong (X1) secara individu terhadap kunjungan di Taman Nusa (Y)

$\mathrm{Hi}: \mathrm{b} 1 \neq 0$, berarti; ada pengaruh yang nyata antara seni pertunjukan tari Barong (X1) secara individu terhadap kunjungan di Taman Nusa (Y)

2) Penentuan Statistik Tabel Sesuai dengan hipotesa alternatif $(\mathrm{Ha})$. Dalam penelitian ini digunakan ?/2 (taraf kepercayaan) $=2,5 \%$ dan $\mathrm{df}$ (degrrees of freedom $=$ derajat bebas) $=\mathrm{n}-\mathrm{k}=80-3=77$, sehingga besarnya ttabel $=\mathrm{t}($ 圆 $/ 2, \mathrm{df})$ yang dicari adalah $\mathrm{t}(2,5 \%, 77)$. Pada Lampiran 8, dalam Tabel t menurut Usman (2010) besarnya $t(2,5 \%, 77)$ adalah 2,0.

3) Menghitung t-hitung diketahui: Thitung $=8,483$

4) Gambar Daerah Penerimaan dan Penolakan Ho

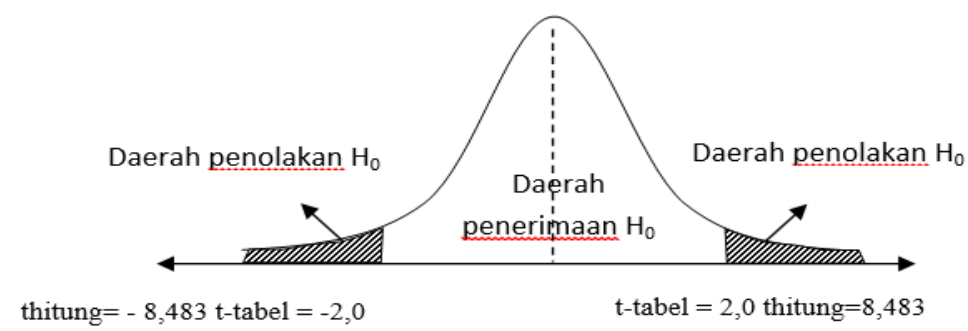

Gambar 2 : Kriteria Penerimaan dan Penolakan Hipotesis Pengaruh Secara Parsial Seni pertunjukan Tari Barong (X1) Terhadap Kunjungan di Taman Nusa (Y) 
Pengaruh seni pertunjukan instrumen angklung (X2) secara individu terhadap kunjungan di Taman Nusa (Y). Untuk mengetahui apakah secara parsial seni pertunjukan instrumen angklung berpengaruh terhadap kunjungan di Taman Nusa adalah memang nyata terjadi (signifikan) atau hanya diperoleh secara kebetulan maka langkah-langkah uji statistiknya adalah:

1) Membuat Formulasi Hipotesis

$\mathrm{H} 0: \mathrm{b} 2=0$, berarti tidak ada pengaruh yang nyata antara seni pertunjukan instrumen angklung (X2) secara individu terhadap kunjungan di Taman Nusa (Y)

Hi : b2 $\neq 0$, berarti; ada pengaruh yang nyata antara seni

$\begin{array}{lrr}\text { pertunjukan } & \text { instrumen } \\ \text { angklung } & \text { (X2) } \begin{array}{r}\text { secara } \\ \text { individu }\end{array} & \text { terhadap } \\ \text { kunjungan } & \text { di } & \text { Taman Nusa } \\ \text { (Y) } & & \end{array}$

2) Penentuan Statistik Tabel Sesuai dengan hipotesa alternatif (Ha). Dalam penelitian ini digunakan ? (taraf kepercayaan) $=5 \%$ dan $\mathrm{df}$ (degree of freedom $=$ derajat bebas) $=\mathrm{n}-\mathrm{k}=80-3=77$, sehingga besarnya ttabel $=\mathrm{t}($ (?), $\mathrm{df})$ yang dicari adalah $t,(2,5 \%, 77)$. Pada Lampiran 8, dalam Tabel t menurut Usman (2010) besarnya $t(2,5 \%, 77)$ adalah 2,0 .

3) Menghitung t-hitung, Diketahui: Thitung $=12,204$

4) Gambar Daerah Penerimaan dan Penolakan Ho

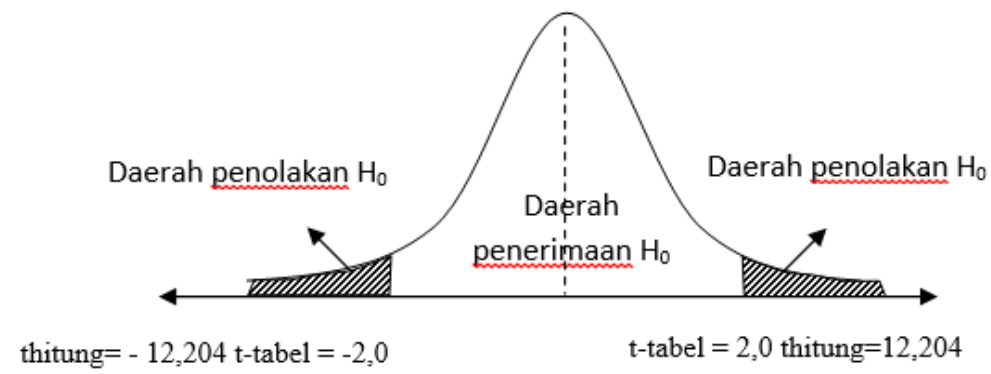

Gambar 3 : Kriteria Penerimaan dan Penolakan Hipotesis Pengaruh Secara Parsial Seni Pertunjukan Instrumen Angklung (X2) Terhadap Kunjungan di Taman Nusa (Y)

5) Kriteria Pengujian

Jika $t_{\text {hitung }}>t_{\text {tabel }}(2,0)$ maka Ho ditolak,

Jika $t_{\text {hitung }} \leq t_{\text {tabel }} \quad(2,0)$ maka Ho diterima,

6) Keputusan dari Gambar 3 di atas tampak jelas bahwa: apabila nilai thitung $=12,204$ dibandingkan dengan nilai ttabel $=2,0$, maka ternyata nilai t-hitung lebih besar dari nilai t-tabel dan t-hitung berada pada daerah penolakan $\mathrm{HO}$, sehingga HO ditolak dan Hi diterima. Ini berarti bahwa ada pengaruh positif yang nyata antara seni pertunjukan instrumen angklung (X2) secara individu terhadap kunjungan di Taman Nusa (Y)
Pengaruh seni pertunjukan tari nusantara (X3) secara individu terhadap kunjungan di Taman Nusa (Y) untuk mengetahui apakah secara parsial seni pertunjukan tari nusantara berpengaruh terhadap kunjungan di Taman Nusa adalah memang nyata terjadi (signifikan) atau hanya diperoleh secara kebetulan maka langkah-langkah uji statistiknya adalah:

1) Membuat Formulasi Hipotesis

$\mathrm{H} 0: \mathrm{b} 3=0$, berarti tidak ada pengaruh yang nyata antara seni pertunjukan tari nusantara (X3) secara individu terhadap kunjungan di Taman Nusa (Y)

Hi : b3 $\neq 0$, berarti ada pengaruh positif yang nyata antara seni 
pertunjukan tari nusantara (X3) secara individu terhadap kunjungan di Taman Nusa (Y)

2) Penentuan Statistik Tabel Sesuai dengan hipotesa alternatif (Ha). Dalam penelitian ini digunakan ?/2 (taraf kepercayaan) $=5 \%$ dan $\mathrm{df}$ (degree of freedom = derajat bebas) $=\mathrm{n}-\mathrm{k}=80-3=77$, sehingga besarnya ttabel $=\mathrm{t}($ 回, $\mathrm{df})$ yang dicari adalah $\mathrm{t}(2,5 \%, 77)$. Pada Lampiran 8, dalam Tabel t menurut Usman (2011) besarnya $t(2,5 \%, 77)$ adalah 2,0 .

3) Menghitung t-hitung, Diketahui: Thitung $=9,772$

4) Gambar Daerah Penerimaan dan Penolakan Ho
5) Kriteria Pengujian

Jika thitung $>$ ttabel $(2,0)$ maka Ho ditolak

Jika thitung $\leq$ ttabel $\quad(2,0)$ maka Ho diterima

6) Keputusan dari Gambar 4 di atas tampak jelas bahwa: apabila nilai thitung $=9,772$ dibandingkan dengan nilai ttabel $=2,0$, maka ternyata nilai t-hitung lebih besar dari nilai t-tabel dan t-hitung berada pada daerah penolakan $\mathrm{HO}$, sehingga HO ditolak dan Hi diterima. Ini berarti bahwa ada pengaruh positif yang nyata antara seni pertunjukan tari nusantara (X3) secara individu terhadap kunjungan di Taman Nusa (Y).

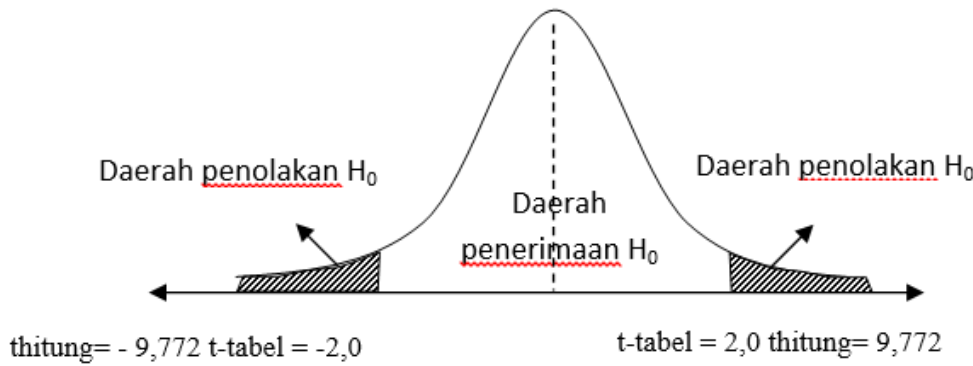

Gambar 4: Kriteria Penerimaan dan Penolakan Hipotesis Pengaruh Secara Parsial Seni Pertunjukan Tari Nusantara (X3) Terhadap Kunjungan di Taman Nusa (Y)

\section{KESIMPULAN}

Berdasarkan hasil penelitian dan pembahasan maka dapat disimpulkan bahwa seni pertunjukan sebagai produk wisata dari PT. Taman Nusa, memiliki pengaruh kuat atau sangat signifikan terhadap tingkat kunjungan wisatawan ke Taman Nusa. Berikut merupakan data pendukung pernyataan tersebut: Hasil penelitian secara parsial: seni pertunjukkan tari barong sebesar 0,697. Karena nilai $\mathrm{r} 1=0,607$ bernilai positif, artinya hubungan yang ada adalah hubungan positif dengan signifikan yang kuat atau searah. seni pertunjukan instrumen angklung sebesar 0,814. Karena nilai $\mathrm{r} 1=0,814$ bernilai positif, artinya hubungan yang ada adalah hubungan positif dengan signifikan yang sangat kuat atau searah. seni pertunjukan tari nusantara sebesar 0,814 . Karena nilai $r 1=0,746$ bernilai positif, artinya hubungan yang ada adalah hubungan positif dengan signifikan yang kuat atau searah. Dari ketiga nilai korelasi parsial tersebut dapat dinyatakan bahwa pertunjukkan instrumen angklung memiliki nilai korelasi yang terbesar, sehingga dapat dikatakan bahwa pertunjukkan instrumen angklung merupakan variabel dominan yang berpengaruh terhadap kunjungan tamu di Taman Nusa.

Berdasarkan perhitungan determinasi diperoleh nilai R2 sebesar $87 \%$, berarti pengaruh seni pertunjukan tari Barong (X1), seni pertunjukan instrumen angklung (X2) dan seni pertunjukan tari nusantara (X3) secara simultan terhadap kunjungan di Taman Nusa (Y) adalah sebesar 87\%. Sisanya 
sebesar $100 \%-87 \%=13 \%$ dipengaruhi oleh faktor lain yang tidak diteliti pada kesempatan ini. Pengaruh seni pertunjukan tari Barong (X1), seni pertunjukan instrumen angklung (X2) dan seni pertunjukan tari nusantara (X3) sebesar $87 \%$ ini, menunjukkan besarnya

\section{DAFTAR PUSTAKA}

Anonim. 2011. "Pengertian Seni". http://www.masterseni.web.id/201 1/12/seni-rupa-pengertian senimenurut-ahli.html. Diakses tanggal 04 November 2015.

Anonim. 2014. "MICE Sebagai Subsektor Pariwisata Ekonomi Kreatif". http://www.parekraf.go.id/userfiles /file/Lapbul\%20Desember\%20201 4.pdf (diakses tanggal 18 februari 2013)

Anonim. 2014. "Studi Lapangan Taman Nusa Gianyar Bali". http://anjelinomenggot.blogspot.co $\mathrm{m} / 2014 / 09 / \mathrm{v}$ -

behaviorurldefaultvmlo.html (diakses tanggal 22 februari 2010)

Dyastriningrum. 2009. "Pengertian Seni Pertunjukan" Jakarta : Pusat Perbukuan, Departemen Pendidikan Nasional.

http://www.lintasjari.com/2013/07 /Diakses tanggal 04 November 2015

Ghozali, I. 2006. Aplikai Analisis Multivarite dengan SPSS. (Cetakan Keempat). Semarang: Badan Penerbit Universitas Diponegoro

$$
\text { Koran Kompas }
$$

(http://www.kompasgramedia.com /diakses pada 13 April 2015).

Kountur. 2007. Metode Penelitian Untuk Penulisan Skripsi Dan Tesis (Edisi Revisi). Jakarta: PPM

Riduwan. 2009. Dasar-Dasar Statistika. (Edisi Ketiga). Bandung: Alfabeta

Satori, dan Komariah. 2009.Metode Penelitian Kualitatif. Bandung: Alfabeta

Soedarso S.P. 2000. Sejarah Perkembangan Seni Rupa Modern. Jakarta: Studio Delapan Puluh Enterprise persentase pengaruh seni pertunjukan tari Barong (X1), seni pertunjukan instrumen angklung (X2) dan seni pertunjukan tari nusantara (X3), untuk meningkatkan kunjungan di Taman Nusa (Y).

Spillane, J. J. 1987. Ekonomi Pariwisata Sejarah dan Prospeknya. Yogyakarta: Kanisius.

Sugiyono. 2013. Metode Penelitian Kuantitatif, Kualitatif dan R\&B. Bandung: Alfabeta.

Supardi. 2013. .Aplikasi Statistika Dalam Penelitian. Jakarta: Change Publication

Umar, H. 2005. Metode penelitian untuk skripsi dan Tesis Bisnis. Jakarta: PT. Raja Grafindo Persada.

Weitz. 1950. Philosophy of the Art. Havard University: Press Cambridge. 